\title{
Integrasi Pasar Ayam Broiler di Sentra Produksi di Jawa Barat dan Pasar Indonesia
}

\section{Market Integration of Chicken Broiler in Production Center in West Java and Indonesian Market}

\author{
Jojo $^{1}$, Harianto ${ }^{2}$, Rita Nurmalina' ${ }^{2}$ dan Dedi Budiman Hakim ${ }^{3}$ \\ ${ }^{1}$ Mahasiswa Pascasarjana S3 Program Studi IImu Ekonomi Pertanian, \\ IPB University, Dramaga Bogor 16880 \\ ${ }^{2}$ Departemen Agribisnis, Fakultas Ekonomi dan Manajemen (FEM), IPB University, Dramaga Bogor 16880. \\ ${ }^{3}$ Departemen IImu Ekonomi, FEM IPB University, Dramaga Bogor 16880 \\ Email: kangjojo06@gmail.com
}

Diterima: 9 Oktober 2020

Revisi: 24 Maret 2021

Disetujui: 14 April 2021

\begin{abstract}
ABSTRAK
Ayam broiler merupakan salah satu komoditas strategis yang tumbuh pesat, dihasilkan oleh subsektor peternakan. Permasalahan umum pemasaran ayam broiler antara lain adalah fluktuasi harga dan kompetisi pasar terhadap harga ayam antar pedagang besar antarkota menyebabkan terjadinya keterkaitan harga ayam satu kota dengan kota lainnya, antar peternak dan pedagang eceran. Tujuan penelitian ini adalah untuk mengkaji integrasi pasar ayam broiler di provinsi Jawa Barat dengan pasar Indonesia. Data yang digunakan merupakan data sekunder time series bulanan, yaitu meliputi 72 bulan, pada periode Januari 2014-Desember 2019. Data dianalisis menggunakan pendekatan model VAR (Vector Autoregression). Hasil analisis menunjukkan bahwa pasar ayam broiler di provinsi Jawa Barat tidak memiliki integrasi dengan pasar Indonesia baik dalam jangka panjang ataupun jangka pendek. Implikasi hasil kajian ini menyebutkan bahwa harga ayam broiler yang dihasilkan oleh peternak (kemitraan internal, kemitraan eksternal dan peternak mandiri) di Jawa Barat tidak dipengaruhi oleh harga ayam broiler di tingkat pedagang besar.

kata kunci: ayam broiler, volatilitas harga, integrasi pasar, VAR
\end{abstract}

\section{ABSTRACT}

Broiler chickens are an overgrowing strategic commodity, produced by the livestock sub-sector. General problems of broiler chicken marketing include price fluctuations and market competition on chicken prices among wholesalers between cities (causing a linkage between prices of chickens among cities) between breeders and retailers. This study aimed to examine the integration of the West Java broiler market and the Indonesian market. The data used are secondary monthly time series data of 72 months, from January 2014-December 2019. The data were analyzed using the VAR (Vector Autoregression) model approach. The analysis results showed that the West Java broiler chicken market does not integrate with the Indonesian market, either on long or short term. The implication of the results of this study states that broiler prices at the wholesales level do not influence the price of broiler chickens produced by farmers (internal partnerships, external partnerships, and independent farmers) in West Java.

keywords: broiler chicken, market integration, price volatility, VAR

\section{PENDAHULUAN}

D aging ayam broiler merupakan salah satu komoditas strategis yang tumbuh pesat, dihasilkan oleh subsektor peternakan selain daging sapi, telur dan susu. Konsumsi tertinggi produk daging per kapita pada tahun 20142017 secara berurutan adalah daging ayam broiler, daging ayam kampung, dan daging sapi (Ditjen PKH, 2019). Berdasarkan data Survei Sosial Ekonomi Nasional September 2018 konsumsi rumah tangga terhadap daging ayam ras secara nasional rata-rata $6,36 \mathrm{~kg} / \mathrm{kapita} /$ tahun atau meningkat rata-rata sebesar 3,92 persen dibanding tahun 2017 dan diperkirakan akan terus bertambah (BPS, 2019). Di samping itu, harga produk ini lebih terjangkau, mudah diperoleh, dan mudah diolah menjadi berbagai macam masakan. Selain itu sektor perunggasan merupakan penyumbang terbesar protein hewani di Indonesia yaitu 65 persen. Nilai 
ekonomi perunggasan Indonesia terbilang besar. Menurut data GPPU 2019 nilai tersebut sebesar Rp428 triliun (Dhamayanti, 2019).

Produksi dan persediaan ayam broiler dalam negeri secara nasional mengalami surplus selama sepuluh tahun terakhir (Ditjen $\mathrm{PKH}$, 2019). Namun demikian, distribusi di setiap wilayah provinsi sangat beragam. Tidak setiap provinsi mampu memenuhi kebutuhan konsumsi daging ayam broiler. Sentra produksi ayam broiler lima tahun terakhir (2014-2018), berdasarkan rata-rata produksinya, terdapat di 6 (enam) provinsi dengan total kontribusi sebesar 72,72 persen atau 1,35 juta ton dari produksi nasional 1,85 juta ton. Dominasi Pulau Jawa sangat terasa dengan melihat 5 (lima) provinsi produsen terbesar berada di Pulau Jawa dengan total kontribusi sebesar 69,12 persen. Urutan kelima provinsi berdasarkan kontribusinya adalah Jawa Barat (35,83 persen), Jawa Timur (12,62 persen), Jawa Tengah (9,53 persen), DKI Jakarta (3,99 persen), dan Banten (7,15 persen). Hal ini membuktikan bahwa Pulau Jawa merupakan sentra produksi ayam broiler dibandingkan luar Jawa (Pusdatin, 2018).

Jawa Barat merupakan provinsi surplus produksi ayam broiler utama di Indonesia yaitu sebesar 13,54 persen pada tahun 2019 (Timorria, 2020). Pada Tahun 2018, produksi ayam broiler di Jawa Barat mencapai 703.000 ton, dengan share sebesar 32 persen dari produksi nasional. Peternak Jawa Barat menjual produk terbesarnya ke pedagang eceran sebesar 47,47 persen, sisanya ke agen $(7,58$ persen), pedagang grosir (15,30 persen), rumah tangga ( 18,85 persen), industri pengolahan $(0,01$ persen), kegiatan usaha lainnya (2,21 persen) penjualan ke luar provinsi yaitu ke DKI Jakarta (8,56 persen) dan Jawa Timur (0,02 persen). Selanjutnya pedagang eceran mendistribusikan paling banyak ke rumah tangga, sisanya ke sesama pedagang eceran, kegiatan usaha lainnya dan industri pengolahan (BPS, 2019).

Salah satu provinsi tujuan perdagangan daging ayam broiler Jawa Barat adalah provinsi DKI Jakarta. Harga daging ayam broiler di DKI Jakarta merupakan referensi harga ayam di Indonesia. Pasokan kebutuhan daging ayam dari luar provinsi DKI, dipasok dari Jawa Barat (69,38 persen), Banten (29,39 persen), Lampung
( 1,03 persen), Jawa Tengah $(0,18$ persen $)$ dan DI Yogyakarta $(0,02$ persen) melalui distributor (4,40 persen), agen (59,2 persen). Pasokan tersebut, didistribusikan pedagang grosir $(34,20$ persen) serta pedagang eceran (2,20 persen) (BPS, 2019).

Permasalahan umum pemasaran ayam broiler di antaranya adalah fluktuasi harga yang tidak menentu dan kompetisi pasar terhadap harga ayam antar pedagang besar yang melibatkan pedagang besar antarkota, sehingga terjadi keterkaitan harga ayam antarkota, antar peternak dan pedagang eceran (Saptana dan Ilham, 2020; Subagja, 2012). Fluktuasi harga yang tinggi menyebabkan disinsentif bagi pelaku usaha sektor perunggasan karena menyebabkan ketidakpastian berusaha. Sisi lain dari harga yang cenderung naik juga merugikan konsumen. Fluktuasi ini disebabkan dalam proses produksi komoditas peternakan bersifat ketidakpastian dan bersifat musiman. Komoditas ini juga mudah rusak dan supply tidak elastis. Sifat musiman berarti pada saat panen supply melimpah, demand tetap maka harga cenderung turun. Sebaliknya pada saat paceklik supply menipis demand tetap (apalagi meningkat) harga cenderung naik. Supply yang tidak elastis berarti tidak dapat memanfaatkan peluang adanya kenaikan harga secara cepat (Daryanto, 2015).

Integrasi pasar merupakan suatu ukuran yang menunjukkan seberapa besar perubahan harga yang terjadi di pasar acuan akan menyebabkan terjadinya perubahan pada pasar pengikutnya. Dua tingkatan pasar dikatakan terpadu atau terintegrasi jika perubahan harga pada salah satu tingkat pasar disalurkan atau ditransfer ke pasar lain. Cahyaningsih, dkk. (2012) mengatakan integrasi pasar memberikan informasi mengenai gejolak harga suatu wilayah dan dampaknya terhadap wilayah lain terutama pada tingkat produsen. Sementara Yustiningsih (2012) mengatakan dalam struktur pasar persaingan sempurna, perubahan harga pada pasar acuan akan ditransfer secara sempurna (100 persen) ke pasar pengikut, yakni di tingkat petani/peternak. Integrasi pasar akan tercapai jika terdapat informasi pasar yang memadai dan disalurkan dengan cepat ke pasar lain sehingga partisipan yang terlibat di kedua tingkat pasar memiliki informasi yang sama. 
Harga ayam broiler di Jakarta menjadi harga referensi bagi pedagang grosir di Bandung untuk menentukan harga basis peternak Jawa barat. Harga di Jakarta juga sering dipakai sebagai basis harga ayam broiler secara nasional dalam penentuan harga. Hal tersebut mengakibatkan perubahan harga ayam broiler di Jakarta sering diikuti perubahan harga di pasar broiler Bandung dan daerah lainnya di Indonesia, sehingga pasar ayam broiler Bandung dengan pasar Jakarta diduga memiliki keterkaitan. Atas dasar inilah penelitian ditujukan untuk mengetahui integrasi pasar ayam broiler di sentra produksi di Jawa Barat dan pasar Indonesia yang diwakili pasar DKI Jakarta.

\section{METODOLOGI}

\subsection{Jenis dan Sumber Data}

Data yang digunakan dalam penelitian ini merupakan data sekunder, berupa data runtun waktu (time series) bulanan dengan periode 72 series, dimulai dari Januari 2014 hingga Desember 2019. Data harga ayam broiler yang digunakan meliputi harga di tingkat produsen (peternak) Jawa Barat sebagai produsen ayam terbesar di Indonesia, diperoleh dari Badan Pusat Statistik. Harga grosir Bandung diperoleh melalui proksi harga di tingkat peternak ditambahkan marjin di tingkat pedagang grosir. Data harga pasar Indonesia direpresentasikan oleh harga konsumen DKI Jakarta yang merupakan konsumen terbesar daging ayam broiler Indonesia. Data tersebut diperoleh dari Badan Pusat Statistik dan kompilasi data dari Kementerian Pertanian Republik Indonesia.

\subsection{Metode Pengolahan dan Analisis Data}

Integrasi pasar ayam broiler dalam penelitian ini merupakan integrasi pasar vertikal dengan melihat pergerakan harga ayam broiler di tingkat produsen, grosir, dan pasar Indonesia yang diwakili oleh harga daging ayam broiler di pasar Jakarta. Jenis ayam yang dianalisis adalah ayam broiler (ayam ras), di mana jenis ayam tersebut merupakan produk ayam yang terbanyak hasil budidaya perunggasan di Indonesia. Data harga ayam yang digunakan dalam kajian ini menggunakan satuan Rp/kg.

Analisis integrasi pasar pada penelitian ini menggunakan model VAR (Vector Autoregression). Data dalam penelitian ini diolah menggunakan Microsoft Excel 2010 dan Eviews 9. Beberapa langkah serta prosedur yang diterapkan dalam analisis ini, di antaranya:

Pertama, uji stasioneritas data. Data time series memiliki kecenderungan data yang tidak stasioner. Data yang tidak stasioner dapat menghasilkan model regresiyang semu (spurious regression). Uji Augmented Dickey-Fuller (ADF test) dilakukan untuk menghindari adanya

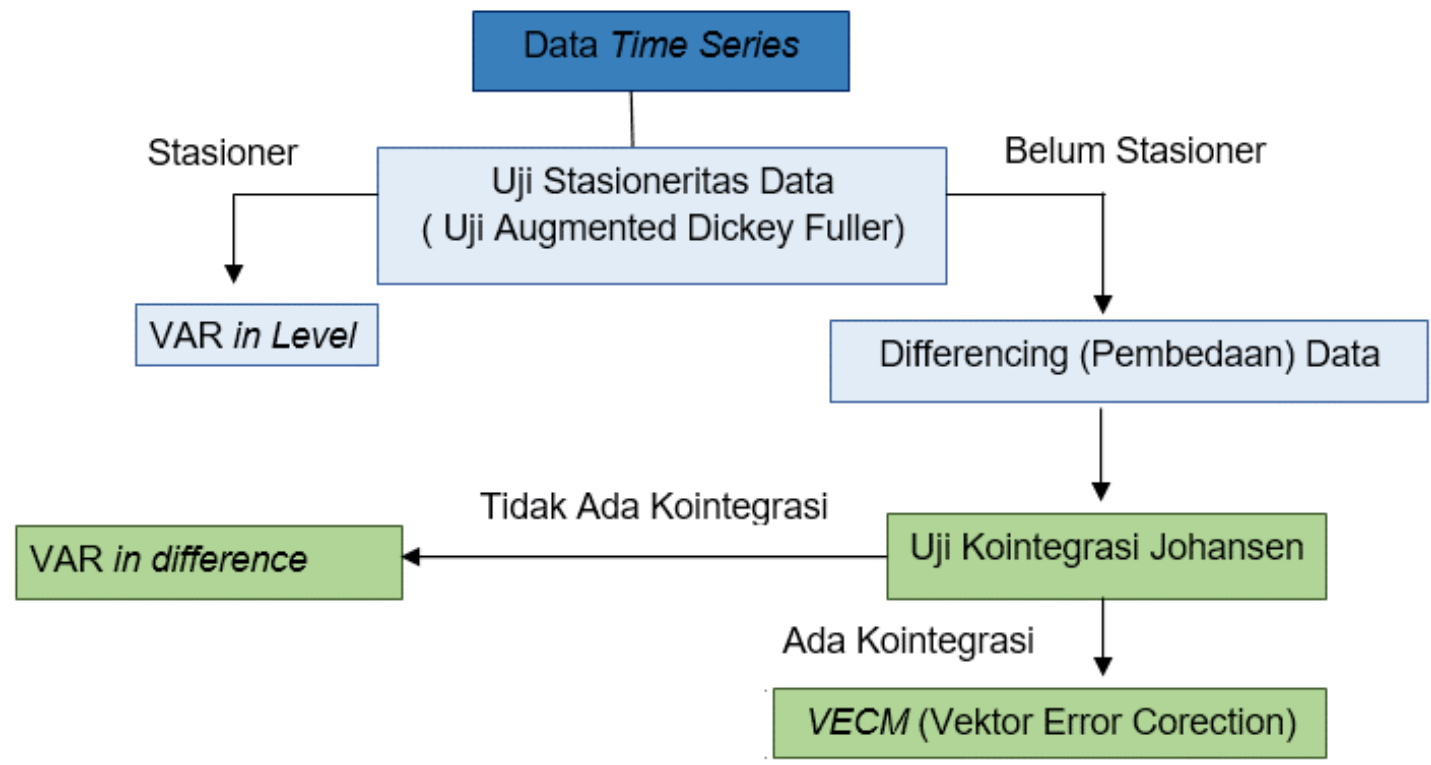

Gambar 1. Skema Penyusunan Model VAR

Sumber : Cahyaningsih, dkk. (2012) 
spurious regression atau hasil pengolahan data yang bias. Suatu data time series dikatakan stasioner pada tingkat level atau I (0) jika nilai uji t lebih besar dari nilai kritis pada taraf nyata 5 persen. Ketika data tidak stasioner pada tingkat level maka perlu dilakukan proses diferensiasi, yaitu dengan mengurangi data tersebut dengan data periode sebelumnya (Ajija, dkk. 2011). Proses diferensiasi dilakukan beberapa kali (d kali) hingga diperoleh pola data yang stasioner.

Stasioneritas memiliki kaitan yang erat dalam penentuan model VARNector Error Correction Model (VECM) yang akan digunakan. Jika data stasioner pada tingkat level maka model yang digunakan adalah VAR in level atau unrestricted VAR. Namun jika data tidak stasioner pada tingkat level tetapi stasioner pada tingkat diferensi, harus diuji apakah data memiliki hubungan kointegrasi. Apabila data terkointegrasi maka model yang digunakan adalah VECM, namun jika tidak terjadi kointegrasi maka model yang digunakan adalah VAR indifference, seperti yang ditunjukkan pada Gambar 1. (Cahyaningsih, dkk., 2012; Widarjono, 2013). 1995) :

Model persamaan umum ADF Test (Enders,

$\Delta P_{t}=\alpha_{0}+\gamma P_{t-1}+\sum_{i=1}^{j} \alpha \Delta P_{t-1}+\varepsilon_{t}$.

Sedangkan formulasi model uji ADF dalam penelitian ini menggunakan persamaan:

$$
\begin{aligned}
& \triangle P F C_{t}=\alpha_{0}+\gamma P F C_{t-1}+\sum_{i=1}^{p} \beta_{1} \Delta P F C_{t-1}+\varepsilon_{t \ldots} \\
& \triangle P B C_{t}=\alpha_{0}+\gamma P B C_{t-1}+\sum_{i=1}^{p} \beta_{1} \Delta P B C_{t-1}+\varepsilon_{t \ldots} \\
& \Delta P I C_{t}=\alpha_{0}+\gamma P I C_{t-1}+\sum_{i=1}^{p} \beta_{1} \Delta P I C_{t-1}+\varepsilon_{t} \ldots
\end{aligned}
$$

Keterangan:

$$
\begin{aligned}
\mathrm{PFC}_{\mathrm{t}}= & \begin{array}{l}
\text { Harga ayam broiler di tingkat } \\
\text { peternak pada periode } \mathrm{t}(\mathrm{Rp} / \mathrm{kg})
\end{array} \\
\mathrm{PFC}_{\mathrm{t}-1}= & \begin{array}{l}
\text { Harga ayam broiler di tingkat } \\
\text { peternak pada periode sebelumnya }
\end{array} \\
& (\mathrm{Rp} / \mathrm{kg}) \\
\triangle \mathrm{PFC}= & \mathrm{PFC}_{1}-\mathrm{PFC}_{\mathrm{t}-1} \\
\mathrm{PBC}_{\mathrm{t}}= & \begin{array}{l}
\text { Harga ayam broiler di pasar Bandung } \\
\text { pada periode } \mathrm{t}(\mathrm{Rp} / \mathrm{kg})
\end{array} \\
\mathrm{PBC}_{\mathrm{t}-1}= & \begin{array}{l}
\text { Harga ayam broiler di pasar Bandung } \\
\text { pada periode sebelumnya (Rp/kg) }
\end{array} \\
\triangle \mathrm{PBC}= & \mathrm{PBC}_{1}-\mathrm{PBC}_{\mathrm{t}-1}
\end{aligned}
$$

$$
\begin{array}{ll}
\mathrm{PIC}_{\mathrm{t}}= & \begin{array}{l}
\text { Harga ayam broiler di pasar Indonesia } \\
\text { pada periode } \mathrm{t}(\mathrm{Rp} / \mathrm{kg})
\end{array} \\
\mathrm{PIC}_{\mathrm{t}-1}= & \begin{array}{l}
\text { Harga ayam broiler di pasar Indonesia } \\
\text { pada periode sebelumnya }(\mathrm{Rp} / \mathrm{kg})
\end{array} \\
\Delta \mathrm{PIC}= & \mathrm{PIC}_{\mathrm{t}}-\mathrm{PIC}_{\mathrm{t}-1} \\
\mathrm{a}_{0}, \mathrm{Y}, \beta= & \text { Koefisien parameter } \\
\varepsilon & =\text { Error persamaan } \\
\mathrm{t} & =\text { Trend waktu }
\end{array}
$$

$\triangle \mathrm{Pt}$ pada persamaan (1) merupakan first difference variabel yang diuji $\left(Y_{t}-Y_{t-1}\right), t$ adalah periode waktu, $p$ adalah panjang lag yang digunakan dan $\varepsilon$ merupakan Error term. Hipotesis statistik yang diuji adalah $\mathrm{H}_{0}: \mathrm{Y}=0$ berarti data time series mengandung unit root, data bersifat tidak stasioner. Jika $\mathrm{H}_{1}: \mathrm{\gamma} \neq 0$ berarti data bersifat stasioner.

Penggunaan aplikasi program Eviews 9 mengategorikan data tersebut stasioner atau tidak, dengan cara membandingkan nilai Mackinnon critical dengan nilai mutlak statistik ADF. Jika dalam uji stasioneritas ini menunjukkan nilai ADF statistik lebih besar daripada Mackinnon critical value, maka data tersebut stasioner karena tidak mengandung unit root. Sebaliknya, jika nilai ADF statistik lebih kecil dari Mackinnon critical value, maka dapat dikatakan data tersebut tidak stasioner pada derajat level. Dengan demikian, perlu dilakukan proses diferensiasi beberapa kali (d kali) hingga diperoleh pola data yang stasioner.

Kedua, penentuan lag optimal. Salah satu permasalahan yang terjadi dalam uji stasioneritas adalah penentuan lag optimal. Jika lag yang digunakan dalam uji stasioner terlalu sedikit, maka residual dari regresi tidak dapat menampilkan proses white noise, sehingga model tidak dapat mengestimasi actual error secara tepat. Penentuan lag optimal berguna untuk melihat seberapa lama suatu variabel bereaksi terhadap variabel lainnya dan menghindari kemungkinan autokorelasi residual pada sistem VAR (Firdaus, 2011).

Penentuan jumlah lag yang digunakan dalam model dapat memanfaatkan beberapa kriteria (Firdaus, 2011) antara lain yaitu Likelihood Ratio (LR), Final Prediction Error (FPE), Akaike Information Criterion (AIC), Schwarz Information Criterion (SC), dan Hannan-Quinn Criterion (HQ). Dalam penelitian ini kriteria yang digunakan 
adalah kriteria Akaike Information Criterion (AIC) dengan rumus umum :

$A I C=-\frac{2 l}{T} A I C=-\frac{2 l}{T}+\frac{2 k 2 k}{T T}$

Keterangan:

$\mathrm{I}=$ log likelihood

$\mathrm{T}=$ jumlah observasi

$\mathrm{k}=$ jumlah variabel yang beroperasi dalam persamaan.

Ketiga, uji kointegrasi. Pengujian kointegrasi bertujuan untuk mengetahui apakah suatu grup yang terdiri dari beberapa data nonstasioner terkointegrasi atau tidak. Salah satu metode pengujian kointegrasi adalah pengujian kointegrasi Johansen. Uji Johansen dilakukan dengan membandingkan antara nilai trace statistic dengan nilai critical value dan maksimum eigenvalue dengan critical value pada taraf nyata 5 persen. Jika trace statistic atau maximum eigenvalue lebih besar dari critical value maka mengindikasikan bahwa dalam sistem persamaan terdapat hubungan jangka panjang atau kointegrasi. Uji yang dilakukan adalah trace test yaitu mengukur jumlah vektor kointegrasi dalam data dengan menggunakan pengujian pangkat matriks kointegrasi yang dinyatakan sebagai berikut (Enders 1995) :

$\lambda_{\text {trace }}(r)=-T \Sigma \ln \left(1-\hat{\lambda}_{1}\right)$

Dan maksimum eigenvalue (ME) dengan persamaan:

$\lambda_{\max }(r, r+1)=-T \Sigma \ln \left(1-\hat{\lambda}_{1+1}\right)$.

Keterangan :

$\lambda_{\mathrm{t}}=$ Nilai dugaan akar karakteristik (eigenvalues) yang didapatkan dari estimasi matriks $\pi$

$\mathrm{T}=$ Jumlah observasi

$r=$ Pangkat yang mengindikasikan jumlah vektor kointegrasi

Pada uji $\lambda_{\text {trace }}, \mathrm{H}_{0}$ adalah jumlah vektor kointegrasi yang hilang $\leq r$ sebagai alternatif umum. Jika $\lambda_{\text {trace }}$ $<\lambda_{\text {tabel }}$ maka terima $\mathrm{H}_{0}$. Artinya kointegrasi terjadi pada rank r. Sementara pada uji $\lambda_{\max }, H_{0}$ yaitu jumlah vektor kointegrasi $=r$ adalah alternatif dari vektor kointegrasi $r+1$. Pada aplikasi Eviews 9, pengambilan keputusan dilakukan dengan melihat nilai trace statistic dan critical value. Jika trace statistic > critical value, persamaan tersebut terkointegrasi. Dengan demikian $\mathrm{H}_{0}=$ non-kointegrasi dengan hipotesis alternatifnya $\mathrm{H}_{1}=$ kointegrasi. Jika trace statistic > critical value, maka tolak $\mathrm{H}_{0}$ atau terima $\mathrm{H}_{1}$ yang artinya terjadi kointegrasi. Jika tidak terdapat kointegrasi antar variabel maka digunakan model VARD (VAR in difference), sedangkan jika dalam data yang diduga di model VAR terdapat kointegrasi maka model VAR yang digunakan adalah model VECM (Firdaus, 2011).

\section{HASIL DAN PEMBAHASAN}

\subsection{Karakteristik Perdagangan Ayam Broiler Jawa Barat.}

Peternak ayam broiler di wilayah Jawa Barat terdiri dari peternak kemitraan pabrikan terintegrasi (kemitraan internal), kemitraan non pabrikan (kemitraan eksternal), dan peternak mandiri. Pada kemitraan internal, harga jual sesuai kontrak. Sedangkan kemitraan eksternal harga jual tidak sesuai harga kontrak, namun mengikuti harga pasar. Peternak lebih banyak memilih usaha dengan sistem kemitraan internal karena risiko harga lebih aman. Jalur distribusi ayam broiler di wilayah Jawa Barat secara umum adalah dari peternak ayam dijual dalam kilogram berat hidup kepada mitra yang biasanya diarahkan kepada rumah potong ayam (RPA) untuk kemudian dijual ke pedagang besar (grosir). Pedagang besar kemudian menyalurkan ke pedagang bakulan untuk seterusnya didistribusikan kepada pedagang pengecer di pasar-pasar tradisional internal Jawa Barat dan daerah sekitarnya, DKI Jakarta dan Banten.

Jawa Barat sebagai sentra produsen utama ayam broiler di Indonesia memiliki peran sangat penting dalam produksi. Jawa Barat merupakan salah satu penentu harga untuk wilayah Jawa dan luar Jawa. Hal ini disebabkan peran Jawa Barat dalam perdagangan ayam broiler cukup besar yakni sekitar hampir 32 persen penghasil daging ayam broiler di Indonesia. Diindikasikan terjadi integrasi vertikal pada peternakan broiler Jawa barat sehingga menyebabkan beberapa implikasi : (i) Bahri, dkk. (2012) mengatakan dengan bermitra, peternak akan mendapatkan jaminan pasokan sarana produksi peternakan dan penjualan hasil, sesuai aturan main yang dipilih dalam pola kemitraan; (ii) Peternak bermitra mendapatkan jaminan keuntungan 
Gambar 2. Perkembangan Harga Ayam Tingkat Peternak, Grosir Bandung dan Pasar Indonesia 2014-2019

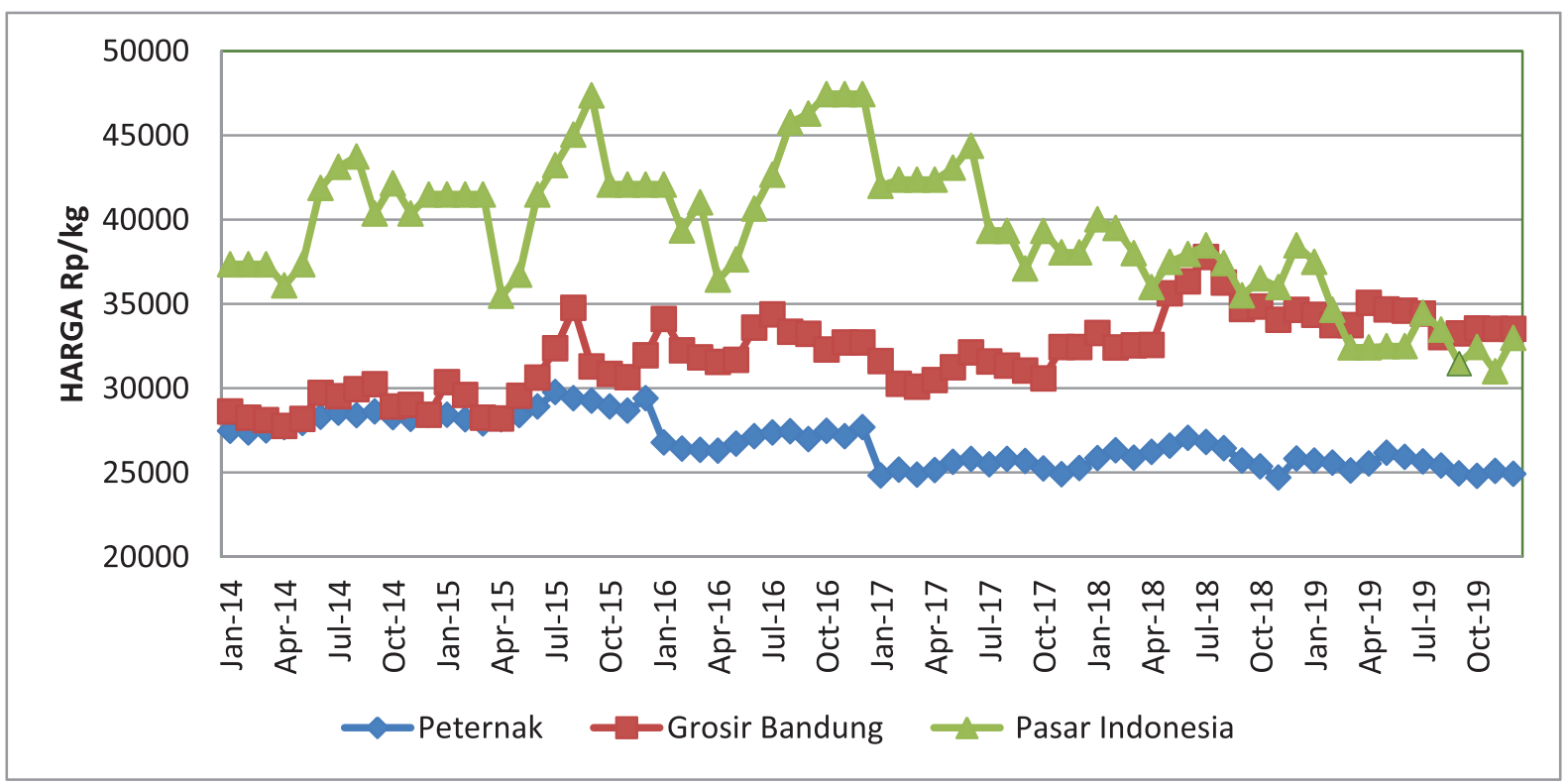

Sumber : Badan Pusat Statistik (2020), diolah.

dan tingkat risiko lebih rendah dibandingkan dengan peternak mandiri. Syarat teknis yang harus dicapai terutama tingkat mortalitas, feed convertion ratio/FCR), umur panen, dan indeks prestasi/lP (Pramita, dkk., 2017); (iii) Sementara, peternak rakyat (mandiri) akan menghadapi dua masalah yaitu menghadapi struktur pasar oligopoli pada pasar input (DOC, pakan, serta vitamin dan obat-obatan) dan struktur pasar oligopsonistik di pasar output (Ilham dan Saptana, 2019; Fitriani, dkk., 2014). Peternak mandiri ini akan menanggung harga input lebih tinggi akan tetapi harus menerima kenyataan harga jual yang lebih rendah dari semestinya. Kondisi ini berdampak pada posisi tawar peternak relatif rendah.

Hargakomoditas peternakan padaumumnya dipengaruhi oleh keseimbangan penawaran dan permintaan. Ayam broiler merupakan salah satu komoditas peternakan tentu mengalami fluktuasi harga baik di tingkat produsen, grosir maupun harga nasional. Salah satu penyebab fluktuasi harga adalah keterkaitan pasar produsen dengan pasar nasional Indonesia. Hal ini karena ayam merupakan komoditas rawan fluktuasi sehingga perkembangan harga sangat dipengaruhi perkembangan harga ayam nasional. Adapun pergerakan harga ayam di tingkat peternak, grosir dan Indonesia disajikan pada Gambar 2.
Gambar 2 menunjukkan bahwa harga daging ayam broiler di tingkat peternak lebih rendah jika dibandingkan dengan harga ayam broiler di tingkat grosir dan pasar Indonesia. Harga yang diterima peternak ditetapkan oleh pedagang (perantara/pengumpul) berdasarkan harga basis yang ditetapkan pedagang besar (grosir). Hal tersebut diduga karena harga di tingkat produsen berperan sebagai price taker, sehingga hanya dapat menerima keputusan harga yang ditetapkan konsumen. (Harianto, dkk., 2019; Fitriani, dkk., 2014). Posisi tawar produsen yang rentan tersebut disebabkan tidak teraksesnya informasi pasar yang cukup, sehingga produsen selalu menerima tingkat harga yang ditetapkan oleh para pedagang. Hal tersebut sejalan dengan hasil kajian Yuningtyas, dkk. (2019), serta Djulin dan Malian (2012). Penurunan harga di tingkat peternak juga tidak ditransmisikan dengan baik ke tingkat konsumen, karena posisi peternak sangat rentan (Saptana, dkk., 2016b)

Berdasarkan nilai koefisien variasinya (CV), dapat dijelaskan bahwa harga di tingkat grosir $(C V=0,071)$ dan Indonesia $(C V=0,105)$ memiliki nilai koefesien variasi yang lebih tinggi di bandingkan dengan pasar peternak $(0,052)$. Artinya, harga ayam broiler di tingkat grosir dan pasar Indonesia memiliki tingkat fluktuasi yang lebih tinggi. Fluktuasi harga jangka pendek 
terjadi karena perubahan harga ayam broiler di pasar Indonesia dipengaruhi oleh harga penawaran periode lalu, harga ayam broiler di pasar grosir dan Indonesia. Adapun harga ayam broiler di tingkat grosir dipengaruhi oleh perubahan harga yang terjadi di peternak. Hal tersebut menyebabkan harga ayam broiler di tingkat grosir berfluktuasi mengikuti pergerakan ayam broiler di tingkat peternak. Sementara, perubahan harga ayam broiler di tingkat produsen relatif stabil.

Realitas industri unggas saat ini dihadapkan pada masalah harga di tingkat peternak yang terus menurun (Rezkisari, 2020). Hal ini diduga akibat kelebihan produksi (over supply) dan meningkatnya harga pakan input yang dipicu kenaikan bahan baku yang masih bergantung pada impor (Umboh, 2014). Selain itu, kerentanan yang lain seperti karakteristik permintaan yang tinggi pada hari raya tertentu (seperti Idul Fitri) menyebabkan fluktuasi harga di tingkat pengecer. Kenaikan harga menjelang hari raya tersebut diduga karena perusahaan pemasok DOC membatasi produksi dan peredarannya, sehingga jumlah ayam yang tersedia di pasaran terbatas. Sesuai dengan hukum permintaan, maka hal tersebut akan memicu kenaikan harga pada hari raya. Gambar 2 juga menginformasikan, pada bulan Juli 2015 menjelang hari raya Idul Fitri, harga di pasar Indonesia Rp43.220,00 pada bulan sebelumnya
Hasil kajian (Saptana, dkk., 2016a) menunjukkan bahwa perkembangan harga bulanan memiliki keterkaitan yang tinggi dengan kebutuhan pangan dalam hal ini ayam di hari-hari besar keagamaan, terutama Hari Raya Idul Fitri. Saat satu bulan sebelum bulan puasa, harga merambat naik hingga mencapai 10-20 persen. Dari pernyataan tersebut, ternyata perubahan tingkat harga yang terjadi di tingkat grosir dan pasar Indonesia tidak seutuhnya sampai di tingkat peternak. Bouchard (2020) mengatakan peternak (produsen) dalam posisi tidak berdaya karena keterbatasan informasi pasar.

\subsection{Evaluasi Hasil Pengujian}

Beberapa langkah pengujian yang diterapkan dalam analisis ini, yaitu uji stasioneritas, lag optimal dan kointegrasi dengan penjabaran sebagai berikut :

Pertama, uji stasioneritas. Uji stasioneritas data harga ayam broiler dilakukan pada setiap tingkatan harga peternak, grosir dan Indonesia dengan menggunakan Uji ADF (Augmented Dickey-Fuller). Dilakukan pengujian stasioneritas harga ayam broiler pada beberapa kondisi yaitu level first difference dan seterusnya. Jika data tidak stasioner pada tingkat level I (0) maka diuji kembali pada tingkat first difference I (1) dan seterusnya, hingga didapatkan data yang stasioner (Tabel 1).

Tabel 1. Uji Stasioneritas Data Harga Ayam Broiler di Tingkat Peternak, Grosir Bandung dan Pasar Indonesia

\begin{tabular}{lcccc}
\hline \multirow{2}{*}{ Variabel } & \multicolumn{2}{c}{ Level } & \multicolumn{2}{c}{ First Difference } \\
\cline { 2 - 5 } & Nilai ADF & Keterangan & Nilai ADF & Keterangan \\
\hline Harga Peternak & $-1,62[0,47]$ & Tidak stasioner & $-9,27[0,00]^{*}$ & Stasioner \\
Harga Grosir & $-2,34[0,16]$ & Tidak stasioner & $-8,21[0,00]^{*}$ & Stasioner \\
Harga Indonesia & $-2,00[0,29]$ & Tidak stasioner & $-8,64[0,00]^{*}$ & Stasioner \\
\hline
\end{tabular}

Keterangan: ${ }^{*}=$ stasioner, pada taraf nyata 1 persen.

Sumber : Badan Pusat Statistik (2020), diolah

harga ayam broiler adalah Rp41.479,00 (terdapat kenaikan harga 4,12 persen). Harga di tingkat grosir pada periode yang sama, menunjukkan harga sebelumnya Rp30.629,00 harga pada bulan Juli Rp32.358,00 (terdapat kenaikan 5,65 persen). Sementara harga di tingkat peternak pada periode yang sama, menunjukkan harga broiler pada bulan Juli Rp29.764,00, sementara harga bulan sebelumnya Rp28.915,00 (kenaikan hanya 2,94 persen).

Hasil uji ADF (Tabel 1) menunjukkan bahwa variabel harga ayam broiler di tingkat peternak, grosir dan pasar Indonesia tidak stasioner pada level I (0). Hal ini didapat dari hasil uji ADF pada level I (0) untuk ketiga variabel memiliki nilai mutlak uji statistik ADF lebih kecil dari nilai kritis Mckinnon. Data yang tidak stasioner pada tingkat level I (0) selanjutnya diuji kembali pada first difference I (1) untuk melihat stasioneritas data. 
Pada tingkat first difference I (1) tersaji bahwa variabel data harga ayam di tingkat peternak, grosir dan harga Indonesia telah stasioner. Hal tersebut ditunjukkan oleh nilai mutlak uji statistik ADF lebih besar dari nilai kritis Mckinnon dan nilai probabilitas yang signifikan pada taraf 1 persen.

Kedua, uji lag optimal. Penentuan lag optimal merupakan langkah penting dalam mengestimasi model VAR/VECM karena lag dari variabel endogen dalam sistem persamaan akan digunakan sebagai variabel eksogen. Tujuan penentuan lag optimal adalah untuk menghilangkan masalah autokorelasi dan asumsi heteroskedastisitas dalam sistem VAR/ VECM (Enders, 1995). Penentuan panjang lag tersebut dapat dilakukan dengan menggunakan kriteria informasi yang tersedia.

Panjang atau besar lag yang dipilih merupakan lag yang menghasilkan kriteria paling kecil. Pada kriteria LR lag optimal yang bisa digunakan adalah lag 5 , sedangkan FPE, dan AIC lag optimal pada lag 2. Adapun pada kriteria SC dan $\mathrm{HQ}$ lag optimal yang dapat digunakan adalah lag 1.

Informasi pada Tabel 2 menunjukkan, penentuan lag dilakukan dalam penelitian ini dengan menggunakan kriteria Akaike Information Criterion (AIC). Berdasarkan hasil uji pada tabel tersebut menunjukkan bahwa lag optimal yang akan digunakan dalam model VAR/VECM adalah lag 2. Oleh karena itu, disimpulkan bahwa lag optimum yang digunakan pada model integrasi pasar daging ayam Jawa Barat dengan Indonesia adalah lag 2. Artinya semua variabel yang ada dalam model ini saling memengaruhi satu sama lain tidak hanya pada periode sekarang, namun variabel-variabel tersebut saling berkaitan sampai pada 2 periode sebelumnya.
Hasil ini berbeda dengan hasil temuan Zahara (2020), kriteria FPE, AIC, SC dan HQ menyarankan lag 1 sedangkan kriteria LR menyarankan lag 3. Panjang atau besar lag yang dipilih merupakan lag yang menghasilkan kriteria paling kecil. Berdasarkan hasil penghitungan panjang lag optimal, kriteria Final Prediction Error (FPE) memiliki nilai terkecil. Dengan demikian panjang lag optimal yang dipilih pada model integrasi pasar kopi robusta Lampung dengan pasar Bursa London adalah lag 1.

Informasi pada Tabel 2 menunjukkan, penentuan lag dilakukan dalam penelitian ini dengan menggunakan kriteria Akaike Information Criterion (AIC). Berdasarkan hasil uji pada tabel tersebut menunjukkan bahwa lag optimal yang akan digunakan dalam model VAR/VECM adalah lag 2. Oleh karena itu, disimpulkan bahwa lag optimum yang digunakan pada model integrasi pasar daging ayam Jawa Barat dengan Indonesia adalah lag 2. Artinya semua variabel yang ada dalam model ini saling memengaruhi satu sama lain tidak hanya pada periode sekarang, namun variabel-variabel tersebut saling berkaitan sampai pada 2 periode sebelumnya.

Hasil ini berbeda dengan hasil temuan Zahara (2020), kriteria FPE, AIC, SC dan HQ menyarankan lag 1 sedangkan kriteria LR menyarankan lag 3. Panjang atau besar lag yang dipilih merupakan lag yang menghasilkan kriteria paling kecil. Berdasarkan hasil penghitungan panjang lag optimal, kriteria Final Prediction Error (FPE) memiliki nilai terkecil. Dengan demikian panjang lag optimal yang dipilih pada model integrasi pasar kopi robusta Lampung dengan pasar Bursa London adalah lag 1. Integrasi pasar kopi robusta Lampung

Tabel 2. Penentuan Panjang Lag Optimal Harga Ayam Broiler di Tingkat Peternak, Grosir dan Pasar Indonesia

\begin{tabular}{ccccccc}
\hline Lag & LogL & LR & FPE & AIC & SC & HQ \\
\hline 0 & $-1794,55$ & NA & $9,10 \mathrm{e}+19$ & 54,47 & 54,57 & 54,51 \\
1 & $-1652,89$ & 266,12 & $1,64 \mathrm{e}+18$ & 50,45 & $50,85^{*}$ & $50,61^{*}$ \\
2 & $-1640,96$ & 21,35 & $1,50 \mathrm{e}+18^{*}$ & $50,36^{*}$ & 51,06 & 50,64 \\
3 & $-1638,87$ & 3,54 & $1,86 \mathrm{e}+18$ & 50,57 & 50,57 & 50,97 \\
4 & $-1633,67$ & 8,36 & $2,10 \mathrm{e}+18$ & 50,69 & 51,98 & 51,20 \\
5 & $-1620,30$ & $20,24^{*}$ & $1,87 \mathrm{e}+18$ & 50,54 & 52,14 & 51,18 \\
\hline
\end{tabular}

Keterangan: ${ }^{*}=$ menunjukkan nilai yang dipilih oleh kriteria

Sumber : Badan Pusat Statistik (2020), diolah 
dengan pasar Bursa London adalah lag 1.

Sedangkan hasil temuan Yuningtyas, dkk. (2019) menyebutkan penentuan lag dilakukan dengan menggunakan kriteria Akaike Information Criterion (AIC). Hasil tersebut menunjukkan bahwa lag optimal yang akan digunakan dalam model VECM adalah lag 3. Maka dari itu dapat disimpulkan bahwa lag optimum yang digunakan pada model integrasi pasar karet alam Indonesia dengan dunia adalah lag 3. Artinya semua variabel yang ada dalam model ini saling memengaruhi satu sama lain tidak hanya pada periode sekarang, namun variabel-variabel tersebut saling berkaitan sampai pada 3 periode sebelumnya.

Ketiga, Jika nilai trace statistics atau maxEigen statistic lebih besar dibandingkan nilai kritis (critical value), maka dapat dikatakan terjadi kointegrasi pada sistem persamaan yang dianalisis. Hasil pengujian kointegrasi pasar daging ayam broiler Jawa Barat dan pasar Indonesia disajikan pada Tabel 3. yang dilakukan dengan menggunakan analisis VAR in Difference (VARD) untuk melihat terjadinya integrasi pasar ayam broiler dalam jangka pendek.

Tidak adanya harga daging ayam broiler terkointegrasi di tingkat peternak, grosir Bandung, dan pasar Indonesia menunjukkan bahwa dalam jangka panjang tidak ada keseimbangan hubungan antara harga di pasar tersebut. Tidak kointegrasi artinya harga daging ayam broiler tingkat peternak, dengan grosir dan pasar Indonesia tidak terintegrasi dan merugikan peternak sebagai produsen karena perubahan (kenaikan) harga di grosir dan pasar Indonesia tidak ditransmisikan ke peternak. Tidak ada transmisi harga menunjukkan kegagalan Hukum Satu Harga (Law of One Price / LOP), di mana sinyal dan informasi harga berada ditransmisikan secara merata sehingga pergerakan harga antara pasar yang berbeda akan sama (Fackler dan Goodwin, 2001).

Tabel 3. Uji Kointegrasi Johansen Harga Ayam Broiler di Tingkat Peternak, Grosir Bandung dan Pasar Indonesia.

\begin{tabular}{lcccc}
\hline $\begin{array}{c}\text { Jumlah } \\
\text { Persamaan } \\
\text { Kointegrasi }\end{array}$ & $\begin{array}{c}\text { Trace } \\
\text { Statistic }\end{array}$ & $\begin{array}{c}\text { Nilai Kritis } \\
\mathbf{( 5 \% )}\end{array}$ & $\begin{array}{c}\text { Max-Eigen } \\
\text { Statistic }\end{array}$ & $\begin{array}{c}\text { Nilai Kritis } \\
\mathbf{( 5 \% )}\end{array}$ \\
\hline None & 20,66 & 29,78 & 15,23 & 21,13 \\
At most 1 & 5,38 & 15,50 & 4,42 & 14,26 \\
At most 2 & 0,96 & 3,84 & 0,96 & 3,84 \\
\hline
\end{tabular}

Keterangan : tidak signifikan pada taraf nyata 5 persen

Berdasarkan Tabel 3 dapat dijelaskan bahwa nilai trace statistic dan maxeigen statistic memiliki nilai yang lebih kecil dari nilai kritis 5 persen. Apabila nilai trace statistic dan max-eigen statistic lebih kecil dibanding nilai kritis maka dapat dikatakan bahwa tidak terdapat hubungan jangka panjang atau tidak ada kointegrasi dalam persamaan tersebut. Semakin besar nilai trace statistic dan maksimum eigenvalue maka semakin tinggi tingkat kointegrasinya. Pada Tabel 3 juga menginformasikan bahwa tidak ada persamaan yang terkointegrasi di antara peubah-peubah di dalam model. Hal tersebut mengandung arti bahwa pasar daging ayam Jawa Barat dan pasar Indonesia tidak terintegrasi dalam jangka panjang. Namun dalam jangka pendek hubungan tersebut dapat saja terjadi. Sehingga perlu dilakukan analisis selanjutnya

\subsection{Analisis Integrasi Pasar Ayam Broiler Jawa Barat dan Pasar Indonesia}

Integrasi pasar ayam broiler Jawa Barat dan pasar Indonesia dianalisis menggunakan metode VAR in defference untuk melihat hubungan jangka pendek. Tabel 4 menunjukkan variabel-variabel yang memengaruhi pembentukan harga di tingkat peternak (PFC), grosir (PBC) dan pasar Indonesia (PIC). Pada jangka pendek perubahan harga ayam broiler hidup di tingkat peternak tidak dipengaruhi oleh perubahan harga periode sebelumnya di tingkat peternak itu sendiri, harga grosir maupun harga pasar Indonesia. Dalam hal ini, pembentukan harga broiler peternak (mandiri dan kemitraan eksternal) saat ini diduga cenderung mengikuti harga posko yang ditentukan PINSAR yang 
merupakan wadah perusahaan-perusahaan besar peternakan dalam penentuan strategi bersama. Hasil ini sejalan dengan hasil kajian Saptana, dkk. (2020), Ningsih dan Prabowo (2017) yang menyebut harga ayam broiler hidup tingkat peternak ditentukan oleh oligopoli perusahaan besar. Di samping itu, peternak kemitraan internal hanya menerima harga sesuai kesepakatan, tidak terpengaruh naik turun harga pasar (Sarwanto, 2004). Hasil ini didukung hasil kajian Harianto (2019) dan Firiani (2014) yang menyebutkan produsen berperan sebagai price taker, sehingga hanya dapat menerima keputusan harga yang ditetapkan pedagang.

Adapun harga grosir dalam jangka pendek dipengaruhi oleh perubahan harga tingkat peternak pada lag kesatu (1 bulan sebelumnya) pada taraf nyata 5 persen, besarnya perubahan sebesar 0,821 . Dengan kata lain, jika terjadi perubahan (kenaikan) harga di tingkat peternak satu periode lalu sebesar 1 persen, maka akan terjadi perubahan (kenaikan) harga di tingkat grosir sekarang sebesar 0,821 persen. Tanda positif tersebut mengindikasikan jika terjadi peningkatan harga daging ayam peternak maka akan direspon oleh pasar daging ayam grosir dengan meningkatkan harga daging ayam dan sebaliknya. Hal ini menunjukkan bahwa pembentukan harga daging ayam tingkat grosir ditentukan oleh perubahan harga daging ayam tingkat peternak. Harga grosir juga dipengaruhi perubahan dua bulan sebelumnya harga Indonesia sebesar -0,091 taraf nyata 20 persen. Pengaruh harga pasar Indonesia bertanda negatif terhadap harga grosir, artinya bila terjadi kenaikan harga sebelumnya sebesar 1 persen di pasar Indonesia maka akan menurunkan harga sekarang di grosir sebesar 0,091 persen.

Di pihak lain, perubahan harga Indonesia dalam jangka pendek dipengaruhi oleh perubahan harga tingkat grosir satu bulan sebelumnya sebesar 0,602 . Artinya, bila terjadi perubahan (kenaikan) harga tingkat grosir satu periode lalu sebesar 1 persen, maka akan terjadi perubahan (kenaikan) harga di tingkat Indonesia saat ini sebesar 0,602 pada taraf nyata 5 persen. Artinya, pembentukan harga di pasar Indonesia ditentukan harga penawaran tingkat grosir Bandung periode lalu. Lain pihak, perubahan harga ayam broiler jangka pendek tingkat pasar Indonesia juga dipengaruhi oleh perubahan harga ayam broiler pasar Indonesia itu sendiri sebesar -0,222 pada periode satu bulan sebelumnya pada taraf nyata 20 persen. Artinya bila terjadi kenaikan 1 persen di harga Indonesia sebelumnya, maka akan menurunkan harga saat ini sebesar 0,222 persen. Hal ini menunjukkan bahwa dalam penentuan harga ayam broiler para pelaku pasar di pasar Indonesia tidak hanya mempertimbangkan penawaran dan permintaan yang terjadi pada periode bersangkutan tetapi juga memperhatikan harga ayam yang terbentuk pada pasar Indonesia periode sebelumnya. Hal demikian menunjukkan bahwa tren harga ayam Indonesia akan mengalami penurunan setiap periodenya jika dilihat dalam jangka pendek (Gambar 2).

Secara keseluruhan hasil analisis VAR menunjukkan bahwa tidak terjadi integrasi antara pasar daging ayam broiler di tingkat produsen, grosir dan Indonesia baik pada jangka panjang ataupun jangka pendek. Hasil ini sejalan dengan kajian Saptana, dkk. (2020); (Saptana, dkk., 2016b); Ningsih dan Prabowo (2017) yang mengatakan pasar broiler di tingkat peternak di daerah sentra produksi di Jawa Barat dan di tingkat pedagang pengecer di Kota Bandung tidak terintegrasi dengan baik. Akibat kurang terintegrasinya pasar tersebut, diduga harga broiler saat ini cenderung mengikuti harga posko yang ditentukan PINSAR. PINSAR merupakan wadah perusahaan-perusahaan besar perunggasan dalam melakukan kesepakatan harga posko bersama. Di samping itu, harga broiler Jawa Barat juga banyak dipengaruhi oleh pasokan dari daerah sentra produksi Bogor dan Bekasi dan harga di tujuan pasar utama DKI Jakarta dan Banten karena secara spasial lokasinya berdekatan.

Menurut Mayer dan von Cramon-Taubadel (2004), harga di antara dua pasar yang tidak bergerak dari satu pasar ke pasar lainnya, dapat disebabkan oleh: biaya penyesuaian, kekuatan pasar yang dimiliki pasar tertentu, kebijakan pemerintah dan informasi yang asimetris. Dengan demikian, untuk meningkatkan integrasi pasar broiler, perlu upaya peningkatan transmisi yang lebih baik dengan peningkatan akses informasi pasar secara transparan. Pasar yang terintegrasi mencerminkan transmisi harga yang simetris. Hal tersebut perlu didukung dengan 
Tabel 4. Estimasi Harga Jangka Pendek Harga Ayam Broiler di Tingkat Peternak, Grosir Bandung dan Pasar Indonesia (VAR in Difference /VARD)

\begin{tabular}{cccc}
\hline $\begin{array}{c}\text { Variabel } \\
\text { Independen }\end{array}$ & $\begin{array}{c}\text { D(PFC) } \\
\text { Variabel Dependen }\end{array}$ & $\begin{array}{c}\text { D(PBC) } \\
\text { Variabel Dependen }\end{array}$ & $\begin{array}{c}\text { D(PIC) } \\
\text { Variabel Dependen }\end{array}$ \\
\hline D(PFC (-1)) & $-0,123673$ & $0,821449^{* * *}$ & 0,574488 \\
& $(0,13891)$ & $(0,22265)$ & $(0,47792)$ \\
D(PFC (-2)) & {$[-0,89031]$} & {$[3,68946]$} & {$[1,20206]$} \\
& 0,085429 & 0,141914 & $-0,190765$ \\
& $(0,15363)$ & $(0,24624)$ & $(0,52856)$ \\
D(PBC(-1)) & {$[0,55607]$} & {$[0,57632]$} & {$[-0,35974]$} \\
& 0,043603 & 0,077082 & $0,601630 * * *$ \\
& $(0,08078)$ & $(0,12948)$ & $(0,27794)$ \\
D(PBC (-2)) & {$[0,53975]$} & {$[-0,59531]$} & {$[2,16463]$} \\
& $-0,033760$ & $-0,098768$ & 0,299925 \\
& $(0,07571)$ & $(0,12135)$ & $(0,26049)$ \\
D(PIC(-1)) & {$[0,44590]$} & {$[-0,81388]$} & {$[1,15139]$} \\
& & & $-0,222268 *$ \\
& 0,005690 & $-0,040749$ & {$[0,13862]$} \\
& $(0,04029)$ & $(0,06458)$ & {$[-1,60348]$} \\
D(PIC (-2)) & {$[0,14122]$} & {$[-0,63102]$} & $-0,056072$ \\
& & & $(0,13559)$ \\
& $-0,039177$ & $-0,091691 *$ & {$[-0,41355]$} \\
C & $(0,03941)$ & $(0,06317)$ & $-143,6304$ \\
& {$[-0,99410]$} & {$[-1,45158]$} & $(263,373)$ \\
& & 113,9023 & {$[-0,54535]$} \\
\hline
\end{tabular}

Keterangan: angka dalam [ ] adalah nilai statistik ${ }^{* *}=$ nyata pada taraf $5 \%$, sedangkan ${ }^{* *}=$ nyata pada taraf $10 \%$ dan ${ }^{*}=$ nyata pada taraf $20 \%$. Adapun Nilai t tabel :t $(\alpha=5 \%)=1,99, t(\alpha=10 \%)=1,66$, dan $t$ $(\alpha=20 \%)=1,29$.

Sumber: Badan Pusat Statistik (2020), diolah.

tersedianya infrastruktur dan sarana informasi yang murah dan mudah diakses secara online. Terintegrasinya pasar broiler akan memberikan dampak pada distribusi margin pelaku usaha perunggasan sehingga tercipta rasa keadilan semua pihak. Hal ini sejalan dengan pendapat Conforti (2004), bahwa transmisi harga dan integrasi pasar akan berjalan sempurna apabila di dalam pasar tidak terjadi friksi dan distorsi. Artinya, pasar akan berjalan secara efisien jika tidak terdapat gangguan-gangguan/ penyimpangan pada pasar, seperti jarak, peraturan (yang ketat/membatasi), dan biaya (overhead cost).

Sedangkan tidak terjadinya integrasi pasar menunjukkan bahwa perubahan harga dalam satu pasar produsen tidak direfleksikan sebagai suatu perubahan harga di pasar produsen yang berbeda secara geografis (Goletti, dkk., 1995; Suryana, dkk., 2014). Lebih lanjut pasar yang tidak terintegrasi ini akan menyebabkan alokasi sumberdaya yang tidak efisien (Faminow dan Benson 1990; Tahir dan Riaz 1997; Meyer dan Cramon Taubadel 2004). Pasar yang tidak terintegrasi dapat membawa informasi yang tidak akurat sehingga dapat mendistorsi keputusan pasar produsen dan kontribusi pergerakan produk menjadi tidak efisien.

Penulis berpendapat, dengan memperhatikan kondisi pasar ayam broiler di Indonesia perlu dipikirkan kebijakan yang memberikan layanan informasi ketersediaan ayam broiler dalam berbagai tingkatan pemasaran, terutama informasi harga yang ada di pasar sentra 
produksi pada periode (momen) menjelang Hari Raya Nasional dan Idul Fitri.

\subsection{Implikasi Kebijakan}

Guna meningkatkan integrasi pasar dapat dilakukan dengan memperbaiki arus informasi dari pusat-pusat pasar konsumsi ke daerahdaerah sentra produksi unggas. Pemerintah melalui instansi terkait disarankan untuk meningkatkan akses informasi harga pasar ayam broiler secara transparan dan biaya terjangkau dengan menyediakan fasilitas dan infrastruktur informasi harga ayam broiler secara online, mempergunakan aplikasi berbasis android/IOS.

Penulis berpendapat, dengan memperhatikan kondisi pasar ayam broiler di Indonesia perlu dipikirkan kebijakan yang memberikan layanan informasi ketersediaan ayam broiler dalam berbagai tingkatan pemasaran, terutama informasi harga yang ada di pasar sentra produksi pada periode (momen) menjelang Hari Raya Nasional dan Idul Fitri.

Kemitraan usaha yang melibatkan peternak menengah dan kecil perlu terus ditingkatkan, terutama dalam skala kawasan sentra produksi peternakan unggas. Dengan demikian, akan terbangun keterpaduan antarpelaku dan keterpaduan proses produk memberikan dampak pada distribusi margin pelaku usaha perunggasan sehingga tercipta rasa keadilan semua pihak.

\section{KESIMPULAN}

Secara umum integrasi pasar yang diindikasikan oleh harga ayam broiler di tingkat peternak di daerah sentra produksi di Jawa Barat dan di tingkat pedagang pengecer di Pasar Indonesia tidak terintegrasi dengan baik dalam jangka panjang ataupun jangka pendek.

Perubahan harga ayam broiler hidup di tingkat peternak Jawa Barat tidak dipengaruhi oleh perubahan harga sebelumnya di peternak itu sendiri, harga grosir Bandung maupun harga pasar Indonesia. Akan tetapi sangat ditentukan oleh kekuatan oligopoli yang cenderung berbentuk oligopoli terpimpin perusahaan perunggasan skala besar melalui penentuan harga posko PINSAR.
Harga grosir Bandung dalam jangka pendek dipengaruhi oleh perubahan harga tingkat peternak satu bulan sebelumnya, yaitu sebesar 0,821 . Harga grosir Bandung juga dipengaruhi perubahan dua bulan sebelumnya dari harga Indonesia sebesar -0,091.

Harga di pasar Indonesia dipengaruhi oleh harga grosir Bandung periode sebelumnya yaitu sebesar 0,601 . Begitupun harga di tingkat pasar Indonesia sebelumnya, dipengaruhi oleh pembentukan harga pasar Indonesia itu sendiri yaitu sebesar $-0,222$. Pembentukan harga di tingkat pengecer lebih ditentukan tingkat penawaran dan permintaan pada periode sebelumnya.

\section{UCAPAN TERIMA KASIH}

Ucapan terimakasih disampaikan kepada Dr. Ir. Harianto, MS., Prof. Dr. Ir. Rita Nurmalina, MS., dan Dr. Ir. Dedi Budiman Hakim, M.Ec. telah memberikan saran dan bimbingannya sehingga terselesaikannya artikel ini. Penulis juga mengucapkan terimakasih kepada BPPDN yang telah memberikan beasiswa studi kepada penulis.

\section{DAFTAR PUSTAKA}

Ajija, S. D. Setianto, dan M. Primanti. 2011. Cara Cerdas Menguasai Eviews. Jakarta: Salemba Empat.

Bahri, D.I., Z. Fanani, dan B. A. Nugroho. 2012. Analisis Struktur Biaya dan Perbedaan Pendapatan Usaha Ternak Ayam Ras Pedaging pada Pola dan Skala Usaha Ternak yang Berbeda di Kota Kendari Provinsi Sulawesi Tenggara. Jurnal Ternak Tropika. Vol.13, No. 1:35-46

BPS. 2019. Distribusi Perdagangan Komoditas Daging Ayam Ras Indonesia Tahun 2019. BPS: Jakarta.

BPS. 2020. Produksi Daging Ras Pedaging Menurut Provinsi 2015-2019. BPS: Jakarta.

Bouchard, D.D. 2020. Essays in Agricultural Economics: Crop Insurance, Vertical Price Transmission, and Spatial Market Integration. PhD Thesis at The North Carolina State University

Cahyaningsih, E., R. Nurmalina, dan A. Maulana. 2012. Integrasi Spasial dan Vertikal Pasar Beras di Indonesia. PANGAN. 21(4):317332. DOI: https://doi.org/10.33964/jp.v21i4.194.

Conforti, P. 2004. Price Transmission in selected agriculture market. Working Paper. FAO Commodity dan Trade Policy Research, 7: 112-125

Daryanto, A. 2015. Kebijakan Stabilisasi Harga Ayam Ras. http://www.troboslivestock.com/detail- 
berita/2015/07/01/22/6300/-arief-daryantokebijakan-stabilisasi-harga-ayam-ras. [Diakses 20 Juli 2020].

Dhamayanti, E. 2019. Daya Saing Industri Perunggasan Nasional. Poultry Indonesia. Tahun 2019. Vol XIV

Ditjen PKH Direktorat Jenderal Peternakan dan Kesehatan Hewan 2019. Outlook Statistik Peternakan dan Kesehatan Hewan 2018. Jakarta (ID): Ditjen PKH

Djulin, A., dan A.H. Malian. Struktur dan Integrasi Pasar Ekspor Lada Hitam dan Lada Putih di Daerah Produksi Utama. SOCA: Jurnal Sosial Ekonomi Pertanian, [S.I.], nov. 2012. ISSN 2615-6628.

Enders, W. 1995. Applied Econometric Time Series. New York (US): John Wiley

Fackler, P and B. Goodwin. 2001. Spatial Price Analysis. Handbook of Agriculture Economics, Vol 1: 972-1018, Elsievier Science, Amsterdam.

Faminow, M.D., and B.L. Benson. 1990. Integration of spatial markets. American Journal of Agricultural Economics. 72(1): 49-62.

Firdaus, M. 2011. Aplikasi Ekonometrika untuk Data Panel dan Time Series. Bogor: IPB Press.

Fitriani, A., K.D. Heny, R. Nurmalina, S.H Susilowati. 2014. Struktur, Perilaku dan Kinerja Industri Broiler Indonesia: Pendekatan Model Simultan. J Agro Ekon. 32 (2): 167-186.

Goletti, F.R., E. Christina-Tsigas. 1995. Analizing Market Integration. London (UK): Lynne Rienenr Publisher.

Harianto, N. Kusnadi, dan D.A. Pramita. 2019. The Impact of Vertical Integration Intensity on Broiler Farms Technical Efciency: The Case of Contract Farming in West Sumatra. Tropical Animal Science Journal, 42(2):167-174

Ilham, N dan Saptana. 2019. Fluktuasi Harga Telur Ayam Ras dan Faktor Penyebabnya. J Analisis Kebijakan Pertanian, 17 (1):27-38

Meyer, J., S.V. Cramon-Taudabel. 2004. Asymetric price transmission: A Survey. Jounal of Agricultural Economics. 4(3): 581-611.

Ningsih, R dan D.W. Prabowo. 2017. Tingkat Integrasi Pasar Ayam Broiler di Sentra Produksi Utama: Studi Kasus Jawa Timur dan Jawa Barat. Buletin IImiah Litbang Perdagangan, (11) 2. Desember 2017.

Pramita, DA, N. Kusnadi, dan Harianto. 2017. Efisiensi Teknis Usaha Ternak Ayam Broiler Pola Kemitraan di Kabupaten Lima Puluh Kota. Jurnal Agribisnis Indonesia. 5 (1): 1-10

Pusat Data dan Sistem Informasi Pertanian. [Pusdatin] 2018. Outlook 20018 Komoditas Pertanian Subsektor Peternakan Daging Ayam. Sekjend Kementrian Pertanian: Jakarta
Reskisari, Indira. 2020. Polemik Harga Ayam Hidup yang Terus Anjlok. https://www.republika.co.id/ berita/q8vloh328/polemik-harga-ayam-hidupyang-terus-anjlok [Diakses 30 Agustus 2020].

Saptana, C. Muslim, M. Maulana, A. K. Zakaria dan D. Trijono. 2016a. Kajian Situasi Pasar Komoditas Broiler: Akar Permasalahan dan Prospek Pengembangannya. Pusat Sosial Ekonomi dan Kebijakan Pertanian. Kementrian Pertanian. Jakarta.

Saptana, M. Maulana, R. Ningsih. 2016b. Analisis produksi dan pemasaran komoditas broiler di Jawa Barat. J Manajemen \& Agribisnis. 14(2):152-154.

Saptana dan N. Ilham. 2020. Pengembangan Rantai Pasok Daging Ayam Secara Terpadu di Jawa Barat dan Jawa Timur. Analisis Kebijakan Pertanian 2020, 18 (1): 41-57.

Sarwanto, C. 2004. Kemitraan Produksidan Pendapatan Peternak Ayam Ras Pedaging (Studi Kasus di Kabupaten Karanganyar dan Sukohardjo). Tesis. Sekolah Pascasarjana Institut Pertanian Bogor.

Subagja, H. 2012. Analisis Kointegrasi Harga dan Usaha Ternak Ayam Broiler di Provinsi Jawa Timur. Disertasi. Program Pascasarjana Fakultas Pertanian Universitas Gadjah Mada: Yogyakarta

Suryana, C., P.S. Asriani, R. Badrudin. 2014. Perilaku harga dan integrasi pasar horizontal beras di provinsi Bengkulu. AGRISEP. 14(2): 131-146.

Tahir, Z., K. Riaz. 1997. Integration of agricultural commodity markets in Punjab. The Pakistan Development Review. 36(3): 241-262.

Timorria, I.F. 2020. Hati-hati, Harga Ayam Bisa BergejolakLagi.BisnisIndonesia.https://ekonomi. bisnis.com/read/20200204/12/1197343/hatihati-harga-ayam-bisa-bergejolak-lagi. [Diakses 25 Januari 2021].

Umboh, S.J.K. 2014. Dampak perubahan harga terhadap kinerja usaha peternakan ayam ras pedaging di Indonesia: analisis model multi market. Disertasi Sekolah Pascasarjana IPB. Bogor.

Widarjono. 2013. Ekonometrika Pengantar dan Aplikasinya Disertai Panduan Eviews. Yogyakarta (ID): UPP STIM YKPN.

Yuningtyas, C.V., D.B. Hakim. dan T. Noviyanti. 2019. Integrasi pasar karet alam Indonesia dengan pasar dunia. Indonesian J. Nat. Rubb. Res. 2019, 37 (2): 139-150

Yustiningsih, F. 2012. Analisa integrasi pasar dan transmisi harga beras petanikonsumen di Indonesia Tesis Universitas Indonesia. Depok.

Zahara. 2020. Integrasi Pasar dan Transmisi Harga Kopi di Provinsi Lampung dengan Pasar Dunia. Tesis Sekolah Pascasarjana IPB. Bogor. 


\section{BIODATA PENULIS:}

Jojo dilahirkan di Garut, 06 Oktober 1974. Penulis menyelesaikan pendidikan D3 Peternakan Unpad pada tahun 1998. S1 Peternakan Universitas Djuanda Bogor lulus pada tahun 2003, dan lulus S2 Magister Manajemen Universitas Mercu Buana Jakarta pada tahun 2008.

Harianto dilahirkan di Buleleng, 21 Oktober 1958.

Penulis menyelesaikan pendidikan S1 Sosial Ekonomi Pertanian IPB lulus pada tahun 1982. Pendidikan S2 Sosial Ekonomi Pertanian IPB lulus pada tahun 1988. Pendidikan S3 ditempuh di La Trobe University Australia, pada tahun 1997.

Rita Nurmalina dilahirkan di Bogor, 13 Juli 1955. Penulis menyelesaikan pendidikan S1 Fak Pertanian IPB tahun 1979, S2 Ekonomi Pertanian IPB tahun 1999, S3 Kebijakan Ekonomi Lingkungan IPB tahun 2007, dan mendapatkan gelar guru besar IPB pada tahun 2011.

Dedi Budiman Hakim dilahirkan di Sumedang, 22 Oktober 1964. Penulis menyelesaikan pendidikan S1 Sosial Ekonomi Pertanian IPB tahun 1988, S2 Ekonomi Pertanian Massey University tahun 1994 dan S3 Ekonomi Pertanian Goettingen University Jerman pada tahun 2004. 